\title{
SURVEY OF NON TIMBER FOREST PRODUCTS (NTFPS) FROM NORTH GADCHIROLI VILLAGES OF MAHARASHTRA.
}

\author{
Pradeep Saudager ${ }^{1}$, Swapnil K. Kamble ${ }^{2}$ \\ ${ }^{1}$ Department of Botany, Arts, Commerce and Science College, Maregaon \\ ${ }^{2}$ Department of Botany, D.D. Bhoyar Art and Science college, Mouda
}

Communicated : 17.12 .19

Revision : 06.01.2020

Published: 30.01 .2020

\begin{abstract}
:
Kurkheda, Korchi talukas of Gadchiroli district are is mainly inhibited Kawar,Gond tribes. Livehood of district are primarily dependent on agriculture, forest collection (NTFPs), agriculture labour, village artisans etc. This area which is selected for survey because of poor indices in various areas of development. Infrastructure, food availability and economics of habitation. Present study deals with 23 plant species belonging to 21 genera and 16 families. This information is obtained by frequent field visits during three seasons of year during 2018.102 rural and tribal families of 7 villages were surveyed.
\end{abstract}

Key words: - NTFPs, tribes, habitation.

\section{INTRODUCTION:}

Worldwide most of the rural tribes are the stakeholders\& non stakeholderwho utilizes Non Timber Forest Products (NTFPs) to fulfill their basic needs. (ICCF,2005)Non-timber forest products (NTFPs) has socio-economic and cultural importance for the forest dwelling communities, particularly for the tropical countries like India(Yadav \& Dugaya, 2013). It also creates conservation of biodiversity aspects within local communities, through this non timber forest products sustainable forest management will be done (Maske et.al.,2011). NTFPsis backbone factor of local tribal communities for enhancing their Social, Economic and Physical Wealth. (Aiyeloja,2006; Agbogidi,2010)Due to heterogeneity of the community and different traditional practices by ethnic groups in the country. NTFP's uses get vary from place to place.

\section{MATERIAL AND METHODS:-}

Information from a North part of Gadchiroli district of Maharashtra on Non Timber Forest Products (NTFPs) was collected based on structured questionnaire and through focused group discussion (Schonhuth and Kievelitz, 1994) involving their relationship with rural and tribal of Gadchiroli district.The information related to NTFPs and suggestions on conservation. Theinterviews were carried out in local language Marathi. The NTFPs plant specimens were collected and identified by standard floras. (Singh et.al 2000; Yadav \& Sardesai 2002)

\section{OBSERVATION}

The list of NTFPs collected in north Gadchiroli region are provided in table.

\section{RESULT AND DISCUSSION}

The present study revealed that NTFPs used by tribal peoples of Kurkheda and Korchi talukas from North Gadchiroli villages for various purposes in Occasional and Regular ways. NTFPs were utilizes in their diets for edible and medicinal purpose. (Chhetri \& Gupta,2010). In above survey villagers obtained NTFPs by collecting fruits, Seeds, Flowers and stem bark from 21 genera with 23 plant species belonging to 16 different families of Dicotyledons. But most of the NTFPs were 
abundantly collected from Fabaceae, Anacardiaceae, Combretaceae, Rhamnaceae than other families.

\section{CONCLUSION}

Now a day the collection activity also decreases because of deforestration and other developmental works like electricity towers going through forest areas,road construction \& increasing population, unsustainable harvesting by the other area and demand of any one species.Day by day the collection were decreases informed by the NTFPs collectors.

\section{REFERENCES}

Agbogidi, A.O. (2010): Ethno-botanical survey of the Non-timber forest products in Sapele Local Government Area of Delta State, Nigeria. African Journal of Plant Science. Vol. 4(3), pp. 183-189. Retrieved on $8^{\text {th }}$ June, 2011 from http://www.academicjournals.org/ajp s.

Ahenkan, A. and Boon, E. (2011): Non-Timber Forest Products (NTFPs): Clearing the Confusion in Semantics. Journal of Human Ecology 33(1): 1-9.

Aiyeloja, A.A. and Ajewole, O.I. (2006): Nontimber Forest Products' Marketing in Nigeria: A case study of Osun State. Educational Research and Reviews. Vol.1 (2), pp. 52-58.

Chhetri, Hari \& Gupta, VNP. (2010). A Survey of Non-timber Forest Products (NTFPs) in Upper Mustang. Scientific World. 5. 10.3126/sw.v5i5.2663.

Farinola L. A., Famuyide O. O., Nosiru M. O., Ogunsola A. J. (2014). Survey of Identified Non Timber Forest Products and Their Role in the Rural Livelihood of Inhabitants of Omo Forest Reserve,
Ogun State. International Journal of Agriculture and Forestry p-ISSN: 2165-882X e-ISSN: 2165-8846 4(4): 317-324 Copyright (C) 2014 Scientific \& Academic Publishing. All Rights Reserved.

ICCF. (2005). Stakeholder organisation in the NTFP sector: Need for a sustainable business model. In Proceeding of National Expert Consultation on NTFP Business Model, 25-26 July 2005.

Maske M. et.al.(2011), Impact of non-timber forest produces (NTFP's) on rural tribes

economy in Gondia District of Maharashtra, India. Archives of Applied Science Research, 2011, 3 (3):109-114.

Mallet, P., \& Karmann, M. (2000). Certification of non-timber forest products: An emerging field. www.fallsbrookcentre.ca.

Pierce, A. R., \& Laird, S. A. (2003). In search of comprehensive standards for nontimber forest products in the botanicals trade. International Forestry Review, 5(2), 138-147.

Pierce, A. R., Shanley, P., Laired, S. A., et al. (2008). Non-timber forest products and certification: Strange bedfellows. Forests, Trees and Livelihoods, 18, 2335.

Shanley, P., Pierce, A. R., Laird, S. A., Robinson, D. et al. (2008). Beyond timber: Certification and management of nontimber forest products. Bogor, Indonesia, Center for International 
Forestry Research (CIFOR). 144p. ISBN: 978-979-1412-44-5.

Sills, E., Shanley, P., Fiona, P., de Beer, J., Pierce, A., et al. (2011). Evolving perspectives on non-timber forest products. In S. Shackleton, C. Shackleton, \& P. Shanley (Eds.), Nontimber forest products in global context. New York: Springer.

SmartWood. (1999). Non timber forest product certification standards addendum. SmartWood, Practical Conservation through Certified Forestry, November, 1999. Retrieved March 1, 2011, from http://www.rainforestalliance.org/forestry/documents/ntfpaddendum-generic-guidelines.pdf.

Schonhuth M. and Kievelitz U. 1994 Participatory Learning Approaches. Rapid Rural Appraisal. Participatory Appraisal. An introductory guide. (Schriftenreihe der GTZ Nr. 248). Eschborn: GTZ.

Stark, M., Min, D., Yongping, Y., et al. (2008). Eco-certification of non-timber forest products in China: Addressing income generation and biodiversity conservation needs. Ecological Economy, 4, 24-34

Singh N P 2000, Lakshminarasimhan P, Karthikeyan S and Prasana P V, (Ed.) B" on plant species studies
Flora of Maharashtra state. Dicotyledons. (Director, Botanical survey of India),(1).

Walter, S. (2006). Certification of non-timber wood forest products: Relevant standards, preliminary experiences and lessons-learnt. Paper presented at the 1st International Conference on Wild Organic Production Teslic, Bosnia Herzegovina, May 3-4, 2006. http://www.fao.org/docs/eims/upload / 229898/OA-NWFP.pdf.

Yadav, M., \& Mishra, S. (2010). Role of role of non-timber forest products based enterprises in sustaining incomes of forest dwellers. In A. Ghosh, Karthik, \& S. Sharma (Eds.), Proceedings (papers) of the international conference on challenges to inclusive growth to emerging economies (pp. 77-81), Ahmadabad: Indian Institute of Management.

Yadav, M. \& Dugaya D. (2013). Non-timber forest products certification in India:

opportunities and challenges., Environ Dev Sustain (2013) 15:567-586.

Yadav S R and Sardesai M M 2002, Flora of Kolhapur District, (Shivaji University, Kolhapur). 


\begin{tabular}{|c|c|c|c|c|c|}
\hline Sr.No. & Local Names & Botanical Names & Family & Part Collected & Remarks(uses) \\
\hline 1 & Awala & Emblica officinalis & Phyllanthaceae & Fruit & Regular \\
\hline 2 & Hirda & Terminalia chebula & Combretaceae & Fruit & Regular \\
\hline 3 & Behada & Terminalia bellirica & Combretaceae & Fruit & Regular \\
\hline 4 & Vaymiri & Embelia ribes & Myrsinaceae & Fruit & Regular \\
\hline 5 & Charoli & Buchania lanzan & Anacardiaceae & Seed & Regular \\
\hline 6 & Tendu & Diospyros melanoxylon & Ebenaceae & Fruit & Ocassional \\
\hline 7 & Godhan & Cordia gharaf & Boraginaceae & Fruit & Ocassional \\
\hline 8 & Bor & Ziziphus mauritiana & Rhamnaceae & Fruit & Regular \\
\hline 9 & Sitafal & Annona squamosa & Annonaceae & Fruit & Regular \\
\hline 10 & Chinch & Tamarindus indica & Fabaceae & Fruit & Regular \\
\hline 11 & Bel & Aegle marmelos & Rutaceae & Fruit pulp & Regular \\
\hline 12 & Palash & Butea monosperma & Fabaceae & Flower & Ocassional \\
\hline 13 & Moh & Madhuca longifolia & Sapotaceae & Flower & Regular \\
\hline 14 & Dowari & Woodfordia fruiticosa & Lythraceae & Flower & Ocassional \\
\hline 15 & Aamba & Mangifera indica & Anacardiaceae & Seed & Regular \\
\hline 16 & Bibba & Semecarpus anacardium & Anacardiaceae & Fruit & Regular \\
\hline 17 & Kusumb & Schleichera oleosa & Sapindaceae & Seed & Ocassional \\
\hline 18 & Karanj & Pongamia pinnata & Fabaceae & Seed & Ocassional \\
\hline 19 & Jambhul & Syzygium cumuni & Myrtaceae & Seed & Regular \\
\hline 20 & Yeroni & Ziziphus oenoplia & Rhamnaceae & Fruit & Regular \\
\hline 21 & Sag,Teak & Tectona grandis & Verbenaceae & Seed & Ocassional \\
\hline 22 & Tarota/Takla & Cassia tora & Fabaceae & Seed & Ocassional \\
\hline 23 & Maidalakdi & Litsea glutinosa & Lauraceae & Stem bark & Ocassional \\
\hline
\end{tabular}

NTFPs producing dicotyledonous 16 Families

- Fabaceae

- Ebenaceae

- Sapindaceae
- Combretaceae

- Boraginaceae

- Myrtaceae
- Rhamnaceae

- Annonaceae

- Verbenaceae

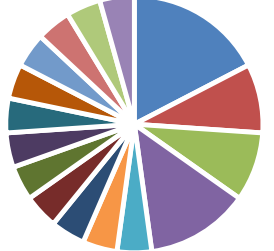

- Anacardiaceae

- Rutaceae

- Phyllanthaceae

- Myrsinaceae

- Lauraceae 